\title{
The Aborigines' Protection Society as an Anticolonial Network: Rethinking the APS "from the bottom up" through letters written by Black South Africans, 1883-87
}

\author{
Darren Reid \\ University College London
}

\begin{abstract}
Histories of the Aborigines' Protection Society (APS) often take for granted that the APS was principally a metropolitan organization, existing primarily in the minds and actions of its members in London. This paper presents a new perspective, highlighting that the APS also existed in the minds and the actions of its global network of settler, missionary, traveller and Indigenous correspondents that provided the APS with information on the conditions of the imperial peripheries. Case studies of letters written by three Black South Africans-John Tengo Jabavu, Mqikela, and Samuel Morokato the APS between 1883 and 1887 are examined. Jabavu wrote from Cape Town, challenging Cape encroachments on African voting rights. Mqikela wrote from Pondoland, challenging Cape encroachments on mPondo territory. Samuel Moroka wrote while visiting London, challenging Orange Free State interference in his succession dispute in Thaba Nchu. Placing these letters within a framework of epistolary mobility, this paper demonstrates how the correspondents used writing to the APS as a tool of anticolonial resistance. More than simply "attempting" resistance, Jabavu, Mqikela, and Samuel Moroka occasionally succeeded in their attempts, convincing the APS to raise their questions in the House of Commons, set up interviews between them and Members of Parliament, and publish their articles in daily newspapers. Yet these successes were always conditioned by an unequal balance of power. The APS could censor and control the voices of Jabavu, Mqikela, and Samuel Moroka when assisting them was no longer in the APS's interest. Approaching the APS from the perspectives of Black South African correspondents offers a new perspective not only on the APS as an anticolonial network, but also on colonymetropole relationships in late nineteenth-century South Africa.
\end{abstract}


The Aborigines' Protection Society (APS) occupies a somewhat paradoxical place in the historiography of the British Empire. The name is inescapable, especially as regards South Africa. It has a strong tendency to appear in histories of any South African event that took place between John Philips' agitation against Khoikhoi exploitation in 1828 to the Zulu Rebellion in 1906. Indeed, it is difficult to find a collection of UK parliamentary papers dealing with nineteenth-century South African affairs that does not include a reference to the APS. On the other hand, despite its apparent omnipresence, the Aborigines' Protection Society is most commonly discussed using a discourse of failure. As Zoe Laidlaw eloquently summarizes:

By almost all standards, the APS can only be judged a failure. Conditions for indigenous peoples around the empire did not improve as the Society's founders had hoped; and their calls for positive imperial intervention fell on increasingly deaf ears as the settler colonies of British North America, Australasia and southern Africa gained control over their internal affairs. ${ }^{1}$

While failure is certainly a valid framing of the APS, it is also metropole-centric. It is a framing which privileges the intentions and agendas of APS members in London, in which "success" and "failure" are judged according to the attainment of metropolitan objectives. To be fair, the APS technically was a metropolitan organization. In the period under study (1883-87) it operated out of 17 King William Street, less than an hour's walk from the Colonial Office headquarters in Whitehall. It revolved primarily around its secretary, Frederick Chesson, as well as a small committee of London-based politicians and philanthropists such as Robert Fowler (Lord Mayor, 1883 and 1885) and William McArthur (Lord Mayor, 1880). But what of the other people whose agency became entangled with the APS: those empire-wide correspondents who engaged with the APS according to their own diverse interests? The Society's correspondence collection at the Bodleian Libraries contains 9,605 individual letters sent to the APS between 1837 and 1909. Most of these letters are from 1866-88, and thus form the temporal framework of this paper. ${ }^{2}$ Roughly 1,400 of these letters are from South Africa, written by around 150 individual correspondents. ${ }^{3}$ Was the APS a failure in the eyes of these correspondents? Why did they expend 1,400 letters worth of ink, paper, 
postage and time in the pursuance of this correspondence, and what does a focus on their correspondence reveal of the APS and of South African experiences of empire?

For one thing, focusing on these correspondents challenges the commonplace notion that the APS was primarily aligned with missionaries and biased against settlers. ${ }^{4}$ In the South African context, the APS is most frequently associated with missionaries like John Philip, Robert Moffat, the Colenso family, John Mackenzie, Eugene Casalis and so on. Simultaneously, the APS is treated as having inherited the 1837 Select Committee on Aborigines' distain for settlers, and to view them as "brutish and acquisitive" ruffians that needed stiff imperial control. ${ }^{5}$ These notions are a fair representation of how the APS members in London understood themselves, but the correspondence reveals that settlers wrote to the APS just as much as missionaries did. Missionaries certainly corresponded for longer and so leave a bigger relative imprint in the archive (the Colenso family alone accounts for more than 300 of those 1,400 letters), yet the breadth of settler correspondence is nonetheless staggering and accounts for around 600 of the 1,400 letters. Some settlers disagreed with the APS and wrote to defend their oppressive treatment of Africans. For instance, one Natal farmer named S.E. Atkinson wrote to the APS on 5 April 1876:

If you had been like myself upwards of a quarter of a century in this country as an employer of Kafirs and engaged amongst them you would know from experience they could not be governed as men.... I regret to say as far as the Kafirs in Natal are concerned, at the present day they are far greater rogues liars thieves... upon an average they are paid 4 times more wages a month than for which they do about half the work. ${ }^{6}$

For the most part, however, settler correspondents exhibited no difficulty in perceiving their interests as in alignment with those of the APS, and the abundance of their letters certainly calls for a reconsideration of the APS's relationship with settler society.

This paper, however, is focused on African letters to the APS, a focus which reveals a presence of African voices which has hitherto been unaddressed within the historiography. These African voices are few and far between-only 37 letters from six correspondents between 1866 and 1888-yet they are no less important for their scarcity. Even more than approaching the APS through the lens of settler letters, 
revisiting the APS through the eyes of its African correspondents reveals an entirely new perspective of the organization. I argue that by looking at the Aborigines' Protection Society from the perspective of its African correspondents, we can perceive it not just as the pro-imperial humanitarian society that its metropolitan members knew it as, but also as the anticolonial network that these correspondents perceived it to be. This paper demonstrates that Africans took advantage of the epistolic space afforded them by the APS to challenge the effects of British colonialism in their territories. I present the letters of three correspondents-John Tengo Jabavu of the Cape Colony, Samuel Moroka of Thaba Nchu, and Mqikela of Pondoland-as case studies. ${ }^{7}$ These cases were chosen based on their sustained correspondence: each wrote upon at least four separate occasions. Two of the other African correspondents-Pambani Mzimba and Kamaherero - wrote only one or two letters which are difficult to extract broader themes from. The sixth correspondent, Shadrach Boyce Mama, also wrote only one letter, and I have written about him elsewhere. ${ }^{8}$ Each of the three correspondents covered in this paper came from a different background, wrote for their own reasons and encountered different responses from the APS. And as I will show, each discovered the APS to be a viable, albeit fickle and uncontrollable, medium for intervening in metropolitan imperial politics from the edges of the empire.

There are some limitations to this paper which should be borne in mind. It is important to note that while the APS was in operation from 1837 untl 1909, each of the letters under discussion was written in the 1880s. My focus on this one decade is partially methodological: the research behind this paper is based on a reading of the 1866-88 letters, and so any arguments put forward should not be generalized beyond the 1860s-1880s. More research into letters from other periods may produce more generalizable results. That said, I focus on the 1880s rather than the 1860s and 1870s because no letter from an African correspondent appears until 1879, and so there does appear to be an aspect of African epistolary engagement with the APS that is specific to the 1880s. This may be related to the temporal specificity that has been identified with the rise of African political organizations in the 1880s, linked to the proliferation of mission schools in the Cape. While mission schools had been a part of the Cape landscape since the eighteenth century, they started to become more accessible and more common from 1854, when the Cape began supplying public funding for mission schools in the eastern territories. The number of elementary- and secondary-schooled 
Africans in the Cape rose from around 9,000 in 1850 to around 100,000 by the end of the century. ${ }^{9}$ When faced with the mass dispossession of the mineral revolution period (1870s-1890s), these mission-educated Africans responded using the Western tools of protest that they had been exposed to at school, forging the first Black political associations: the Native Educational Association in 1879, the Imbumba Yama Nyman in 1882, and the Thembu Association and the South African Native Congress in 1884. Supplementing these groups, the first Black political newspapers were formed to connect disparate Black communities and disseminate Black perspectives: Imvo Zabatsundu (Native Opinion) in 1884, followed by Izwi Labantu (The Voice of the People) in $1898 .{ }^{10}$ That two of the three APS correspondents under discussion-John Tengo Jabavu and Samuel Moroka - were mission-educated and wrote in the same period as the proliferation of African political institutions suggests that epistolary engagement with the APS was also connected to the increasingly Westernized landscape created by mission schools in the late nineteenth century. Note also that this paper is further limited to the geographical context of the Cape Colony. Colonial attitudes towards the APS, as well as APS attitudes towards the colonies, varied significantly across the spaces of the empire, meaning that the experiences of African correspondents cannot be assumed to be shared with correspondents of, say, New Zealand or Canada.

As is quickly apparent, there appears to have been a class-related barrier to corresponding with the APS: Jabavu, Mqikela, and Samuel Moroka all hailed from upper-class or royal backgrounds. The cost of paper, writing tools and postage to England certainly formed one aspect of this barrier, yet I am unconvinced that it formed a major aspect. Many people, especially mission-educated people, had access to paper and writing tools, and the one shilling cost of postage to England was costly but not exorbitantly so. As Vukile Khumalo and Lize Kriel have shown, it was not uncommon for Africans to write to each other, to missionary societies or to local governments in the nineteenth century. ${ }^{11}$ Rather, it seems more likely that access to knowledge about the APS was a more significant factor. To write to the APS, a potential correspondent must first be aware that the APS existed, and so likely needed to be a regular reader of mainstream colonial or British papers like the Cape Times or The Standard. This is a style of media literacy beyond the epistolary literacy necessary to write a letter, and so placed a class barrier upon writing to the APS which was higher than writing to a friend 
or a local government. ${ }^{12}$ Furthermore, a potential correspondent must also have a good idea of the address of the APS's secretary. To be sure, this was not as definite a requirement as it is in the twenty-first century. It was often enough to address a letter to "The Aborigines' Protection Society, London," and postmasters would forward it on to their known address. There are several angry letters from the Postmaster General of Natal to the APS complaining of this, requesting the APS to inform all correspondents of its full address to avoid the inconvenience of looking it up. ${ }^{13}$ There is also the context of the archive to consider. Thirty-seven of the 1,400 letters from South Africa to the APS were written by Africans, but are these merely the letters determined by whoever organized the archive to be important? Charles Swaisland, who worked extensively on researching and organizing the APS collection at the Bodleian, notes that prior to being rescued in 1948 the Society's correspondence archive had been languishing in a damp and moldy cellar on Vauxhall Bridge Road, and that many letters had been destroyed by mold. ${ }^{14}$ Could some of those destroyed letters have been from Africans? Could African letters simply have been discarded by custodians because they were deemed unimportant? All this is to say that the letters under study certainly seem to display a class bias, but it is up to debate as to how much of this class bias was experienced on the African end of letter-writing, and how much was experienced on the British end of archiving.

\section{An Anticolonial Network?}

To suggest that the Aborigines' Protection Society was an "anticolonial network" in South Africa may seem absurd given the extent to which the society was complicit in discourses of imperialism, particularly in the late nineteenth century. From the shortlived annexation of the Transvaal in 1877 to the annexation of Zululand in 1887, a total of ten South African territories were incorporated into the empire. ${ }^{15}$ From one perspective, the APS denounced many aspects of this expansion, and maintained a barrage of protest and critique. ${ }^{16}$ Yet the APS was also, somewhat paradoxically, highly supportive of the annexation of South African territory. This came down to the APS's overarching understanding of empire in the late nineteenth century. It was highly critical of the injustices that often arose during the expansion of empire; it was entirely comfortable with imperialism itself. Indeed, the Society considered the best means of reducing the injustices of imperialism to be increasing Britain's imperial presence and instituting a stronger central administration system. Thus, when it came 
to the annexation of South African territories, the APS was comfortable in supporting the imperial project itself while protesting what it perceived to be cases of excessive violence. Consider the Society's response to the Anglo-Zulu War of 1879. Following the war, reports of terrible atrocities committed by British soldiers had reached Britain and the Society published these accounts and sent formal protests to the Colonial Office. ${ }^{17}$ Yet the Society was simultaneously in favour of annexing Zululand for "the introduction of civilized institutions into native districts and the repression of the military habits of a barbarous race."18 To rationalize this paradox, the APS reasoned that "a policy which in the abstract is good, may yet be made cruel and oppressive by the manner in which it is carried out."19

From this perspective, the APS was complicit in the imperial conquest and colonization, and historians have been quick to highlight this complicity. For instance, James Heartfield argues that the APS played a fundamental role in the development of "humanitarian imperialism," a unique form of imperialism in which territorial expansion was justified not by economic or strategic incentive, but by the "benefit" to be gained by Indigenous populations. ${ }^{20}$ Brian Willan further demonstrates that the APS (after 1909 known as the ASAPS: Anti-Slavery and Aborigines' Protection Society) intentionally worked to silence resistance from the South African Native National Congress (SANNC) against the Natives Land Act of 1913. ${ }^{21}$ These critiques of the Society's complicity in colonizing African peoples and spaces are entirely warranted. At least, the complicity of its political mission is warranted. The Society's political mission was to improve Indigenous-settler relations by both placing Indigenous peoples under the benevolent rule of a strong central government, and by supporting the "improvement" of Indigenous peoples themselves. African correspondents, however, did not write to the APS in the pursuance of this colonizing mission. As will be seen, each of the three correspondents under study wrote letters to co-opt the APS into fighting their local battles against colonial governments within the sphere of metropolitan politics. It is this co-optation by African correspondents that I point to as the anticolonial element of the APS.

\section{African Voices}

Recent scholarship has given increased attention to African letters as historical evidence. Two edited volumes in particular, Karin Barber's Africa 's Hidden Histories 
and Adrien Delmas and Nigel Penn's Written Culture in a Colonial Context, have substantially added to the scholarship of African epistolarity in the South African context. These chapters have explored how African epistolary literacies were exercised to assert class identities, ${ }^{22}$ to escape the censorship of colonial states,${ }^{23}$ to manage family affairs and relationships,${ }^{24}$ and to seek redress from missionary and government organizations. ${ }^{25}$ In the context of the Aborigines' Protection Society, however, African letters have been both marginalized and explicitly denied. Charles Swaisland was certainly aware that Africans wrote to the APS: his dissertation includes an index of all the correspondents he identified during his research, and this index names all the African correspondents that I myself identified. ${ }^{26}$ Yet no reference to their actual letters appears throughout the dissertation itself. Brian Willan's analysis of the Anti-Slavery and Aborigines' Protection Society's responses to the 1913 Native Lands Act includes some African voices, identifying the central role of the South African Native National Congress (SANNC) in pushing the Society to lobby for the Act. Yet in Willan's narrative the SANNC is secondary to the APS, important for how they were treated rather than for what they did. Ronald Rainger's intellectual history of the APS makes no reference to African contacts whatsoever. ${ }^{27}$ Roderick Mitcham excuses himself from attending to African letters to the APS by suggesting that they did not exist:

Owning to the absence of the voices of the suffering, the thesis focuses on the numerous actors who claimed to speak for them. The suffering, within the archive, are not speaking subjects, they are objects of discussion: recuperating their consciousness, therefore, would be highly problematic. ${ }^{28}$

James Heartfield does occasionally reference prominent African voices such as Cetshwayo and Langalibalele that appear in the APS's own publications, and briefly mentions Jabavu as "an important contact for the society," 29 but gives little attention to his writings or to the other African correspondents.

The only historians who have asserted the existence and the importance of African engagement with the APS are Elizabeth Elbourne and Zoe Laidlaw. Elbourne surveys a variety of Indigenous engagements with humanitarian networks, from attending schools run by the London Missionary Society to travelling to Britain under the support of the Aborigines' Protection Society, and argues that Indigenous peoples 
of the empire "took advantage of transnational networks to gain knowledge of other groups and to attempt to negotiate within tight limits with powerful settler states." ${ }^{30}$ Zoe Laidlaw provided case studies of nine individuals who embarked on delegations to England with the support of the Society, demonstrating how each individual strategically leveraged performances of "civility" and "savagery" to increase the effectiveness of anticolonial resistance via public demonstrations and speeches hosted by the APS. ${ }^{31}$ To be fair, we should recognize that these historians were writing at different moments in time. Elbourne and Laidlaw, writing in 2005 and 2014, are of an academic environment that encourages and prioritizes marginalized voices. Swaisland, writing in 1968, was observing processes of decolonization and the fading of the British Empire, and understandably was concerned with reimagining British identities. Willan's article, written in 1979, can be located within the heightened international attention that was directed towards the anti-apartheid liberation movement following the Soweto Uprising in 1976, a moment when people around the world were increasingly interrogating their own societies' roles in supporting apartheid. However, while locating these historians in their temporal context can help explain how they treat African voices, this does not subtract from the importance of including these voices in the history of the APS.

The studies by Elbourne and Laidlaw represent the entirety of historical attention to African engagement with the APS, and these studies have only cracked the surface. They focus largely on delegations to England that were supported by the APS, and while these were significant and visible engagements, they were far from the most common. ${ }^{32}$ The APS's objective was not to bring delegations to testify in England. Rather, as laid out in its first annual meeting, the first object of the Society was "to open a correspondence with intelligent and benevolent individuals abroad" and thereby collect and publish "authentic information concerning the character, habits, and wants of uncivilized tribes." 33 Consequently, the most common means of engaging with the Society was through correspondence. 


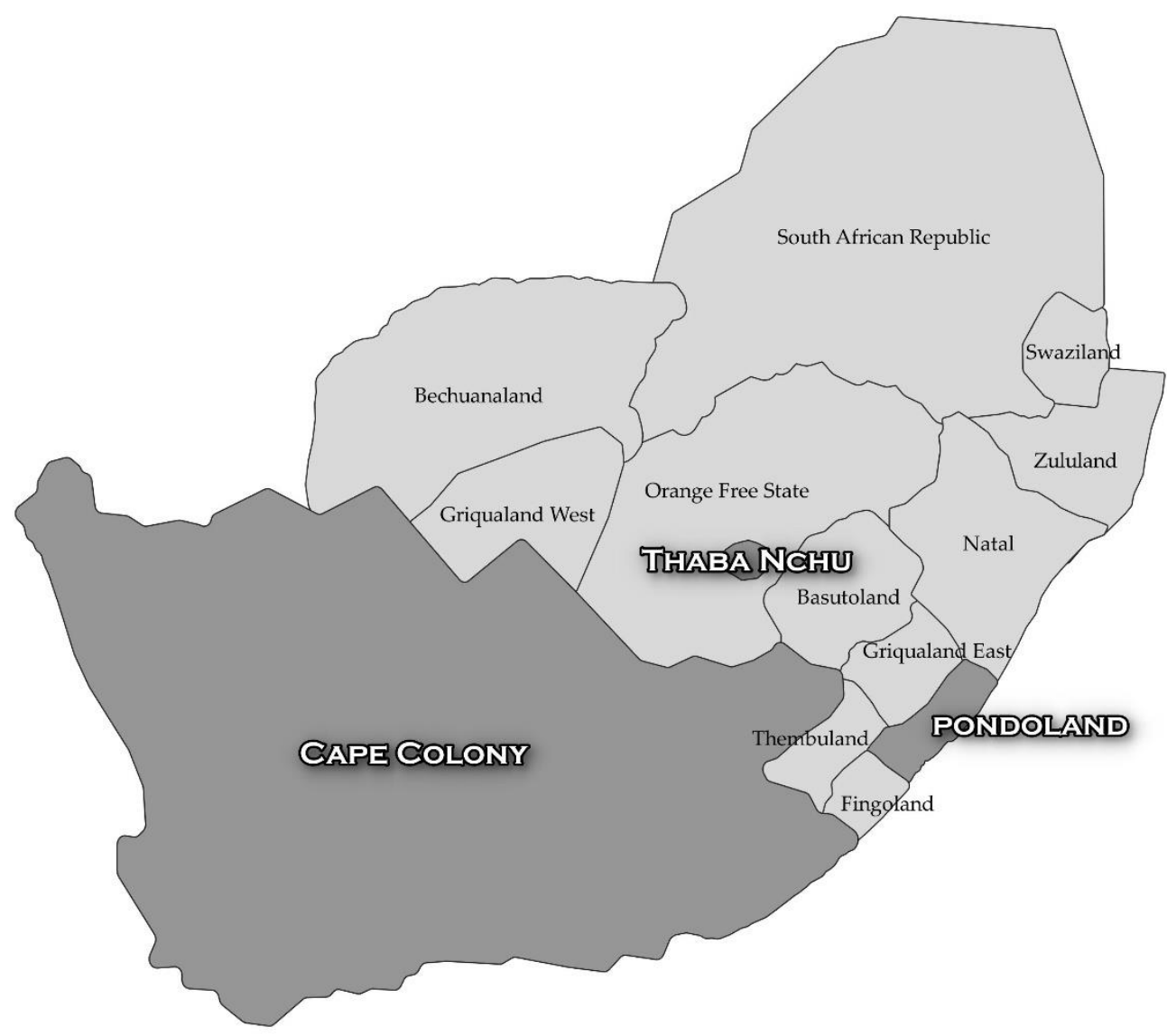

Figure 1: Approximate boundaries of the Cape Colony, Pondoland, and Thaba Nchu in relation to surrounding regions, circa 1885. Created in QGIS by Darren Reid. 


\section{Jabavu}

My first case study, John Tengo Jabavu, was a mission-educated Mfengu journalist from the eastern Cape. Jabavu completed elementary school at the Heald Town mission station and afterwards worked as an elementary school teacher at a Methodist school in Somerset East. While teaching, he also worked as an apprentice for a Somerset East newspaper and studied privately for the University of Cape Town matriculation certificate (equivalent to a modern high school diploma). From 1881 to 1883 he worked as the editor of Lovedale College's Xhosa journal Isigidimi Sama-Xhosa, and in 1883 he became the second African to successfully pass the matriculation exams. ${ }^{34}$ In 1884 , he left Lovedale to establish his own newspaper, Imvo Zabantsundu. Imvo was the first African language newspaper published outside the control of missionary organizations, and its goal was to present African perspectives and support African interests, but it has since been criticized as a mouthpiece for the South Africa elite and for the White politicians who provided Jabavu with funding. ${ }^{35}$

Jabavu wrote a total of eighteen letters to the APS, sent between 1880 and 1887, most of which were about the Parliamentary Registration Act (PRA) of 1887. The PRA was a reaction to rising African voter registrations in the Cape Colony, which allegedly threatened White political supremacy. The 1853 Cape Constitution Ordinance had guaranteed a nonracial franchise, unique among the four South African settler colonies, but it had done so in a context in which the African population posed little political threat. Before British Kaffraria was annexed in 1866, Whites outnumbered Blacks by nearly two to one. ${ }^{36}$ With the annexation of British Kaffraria, Fingoland and Thembuland, the demographics had reversed. By the 1891 census, the White population had fallen to 25 percent and the Black had risen to 55 percent. ${ }^{37}$ African voter registrations rose alongside the African population, and the Parliamentary Registration Bill was introduced in 1886 to stop this trend. The ostensible purpose of the Bill was to "make better provision than at present exists for the proper and complete registration of persons entitled to vote" by devolving the responsibility for drafting voter lists from civil commissioners to local government officers. ${ }^{38}$ However, buried in the seventeenth clause was the following: "No person shall be entitled to be registered as a voter by reason of his sharing in any communal or tribal occupation of lands, or places of residence." 39 The catch-all qualifier of "communal or tribal occupation of lands" disqualified a large number of Africans who had previously 
fulfilled the property qualifications by their claims to portions of communal land, and since it was extremely uncommon for colonists to occupy communal land, the act targeted Africans without explicitly being racial discrimination. ${ }^{40}$

The story of the PRA is typically expressed in terms of the decline of Cape liberalism, and Jabavu is often at the heart of this narrative. The notion of Cape liberalism is itself a complicated one. It is true that of all the other constitutions of South Africa - namely Natal, the Orange Free State and the South African Republicthe Cape Colony's franchise was the most open to African voters. ${ }^{41}$ Yet it is also true that the Cape's famous liberal franchise was not of the Cape's own choosing, but was essentially forced upon the Cape by the imperial government as a condition of representative government. ${ }^{42}$ Regardless of the "true" extent of Cape liberalism prior to 1887 , the introduction of the PRA was certainly a move in the opposite direction and signified the beginning of the end to whatever liberal tradition did exist. This trajectory of anti-liberalism would continue with the 1891 Franchise and Ballot Act, the 1893 Constitution Ordinance, the 1894 Glen Grey Act, and culminate with the complete disenfranchisement of Africans in $1936 .{ }^{43}$ But this trajectory did not go unchallenged, and no one is recognized as doing more to challenge the PRA more than John Tengo Jabavu.

According to the historiography, Jabavu primarily challenged the PRA through his newspaper, Imvo Zabantsundu. Since its inception in 1884, Jabavu had used Imvo to support the African franchise in two different ways. First, by publishing articles encouraging and instructing Africans on how to register to vote, Imvo has been credited as one of the factors driving the spike in African voters that so concerned White politicians in the 1880s. ${ }^{44}$ Second, by publishing articles which emphasized African loyalty to Britain and subservience to White politicians, Imvo "sought to allay white anxieties regarding the growing voting influence of Africans." ${ }^{45}$ Given his longstanding advocacy for African voting, it is unsurprising that Jabavu took the lead in opposing the PRA. To be clear, Jabavu was not the only African to oppose the PRA. At least four public meetings in protest of the PRA were held in different eastern Cape districts throughout June of $1887 .{ }^{46}$ Ten mFengu leaders from the Oxkraal location in the eastern Cape sent a petition to Queen Victoria dated July 1887, which humbly requested the PRA be overturned. ${ }^{47}$ In the midst of this widespread activity, Jabavu's 
name has become most associated with the opposition movement because Imvo connected it together, circulating African demands and mobilizing opposition efforts. However, a problematic consequence of understanding Jabavu's opposition to the PRA only in terms of Imvo is that his political activity takes on the appearance of "local" politics only. Jabavu himself is often understood as a self-consciously "imperial subject," someone who felt deeply attached to an imperial identity and who actively performed his own version of "Britishness." ${ }^{4}$ With attention having been given only to his local opposition politics through Imvo, Jabavu has been placed in an odd sort of perpendicular duality in which he perceived himself as an imperial subject yet took action only at the local level. On the contrary, Jabavu's correspondence with the APS clearly demonstrates an active participation at an imperial level as well.

Jabavu's first letter on the subject, dated 28 March 1887, informed the APS of the introduction of the Parliamentary Registration Bill, which he called "the disenfranchisement bill," and that a group of Africans were organizing against it.

These lines are written with the object of giving you a note of warning.

We are marshalling the local forces to defeat the measure, but with a

Dutch majority in the Cape parliament we fear the battle will have to be fought out in England and that by your useful society. ${ }^{49}$

The "we" that Jabavu refers to is the Native Educational Association, of which Jabavu was vice-president. In response to the PRA, the Native Educational Association had established a committee to organize a deputation to the Colonial Office, and Jabavu informed the APS that "it is just possible I may be of the number, and I cannot say how glad I would be to be permitted to meet you Mr Chesson, my friend face to face and our other English friends." 50

Jabavu asked the APS to help fight the PRA in three ways. First, on 2 July 1887, he asked for a member of the APS to "put a question in the House of Commons as to whether this right—-free hand [i.e. responsible government] — went to the extent of allowing the Cape ministry of the day to tamper with the Constitution to the extent of disfranchising the native." 51 By having this question raised in parliament, Jabavu hoped that the imperial government would realize the unconstitutionality of the PRA and disallow it. Second, on 12 July 1887, he asked for aid in sending a delegation to 
protest the PRA. Here, Jabavu referenced a letter he had sent to Cape Governor Hercules Robinson "to ascertain... whether in the event of the disfranchisement bill passing, our people would have time between its passing and its proclamation to petition the governor and the Queen." ${ }^{52}$ Although the Cape had been granted responsible government in 1872 , the Crown still maintained the rights of reservation and disallowance. When a bill was passed through a colonial parliament, it would be given to the governor for final approval. If the governor felt that the bill significantly changed the legal or political systems of the colony, they would "reserve" the bill for consideration by the British parliament. Jabavu's hope was that the PRA would be reserved for imperial consent and subsequently struck down. Jabavu transcribed Robinson's reply, that "at present His Excellency is under the impression that it will not require to be reserved," and concluded that "there is no time, but the Secretary of State should be interviewed at once, so that he may instruct the Governor to reserve the Bill."53 To achieve this end, he explained that "at Port Elizabeth a mass meeting of natives has resolved to send a delegation to England to plead their cause before the Secretary of State," and he prompted of the APS, "I trust you will do all you can for the delegation when it comes." 54

It is at this point that Jabavu made his third and largest request of the APS, that it would stall any parliamentary deliberation over the PRA until after his delegation could arrive. In his letter of 29 August 1887, Jabavu wrote:

We are still making preparations for furthering our appeal to the Home Government, and we trust if you see fit you will urge upon the Colonial Secretary to suspend recommending the giving of the royal assent to the measure until the delegation reaches London to plead their cause. ${ }^{55}$

He repeated this request on 19 September, demonstrating its importance to him: "I need not add more further than to say do all you can to prevent the Secretary of State not to close the matter until at least he has heard us." ${ }^{, 56}$

The Society became involved in the issue from the very first letter Jabavu wrote on the subject, declaring its support in the October 1887 issue of The Aborigines' Friend: 
We learn from a letter which Mr. Tengo Jabavu wrote to us on July 17th, that at Port Elizabeth a mass meeting of natives have resolved to send a delegation to England to plead their cause in Downing Street. The natives are well advised in taking energetic steps for the defence of their rights, and we shall do all in our power to help them. ${ }^{57}$

The Society also immediately fulfilled Jabavu's request to raise a question in parliament on the matter. APS-affiliated Alexander McArthur raised a question in parliament on 7 July 1887, asking Colonial Secretary Henry Holland "whether the adoption of a measure which seems calculated to disfranchise large numbers of Her Majesty's coloured subjects... would constitute a violation of the conditions on which responsible government was granted to the Colony?"58 Thus, in Jabavu's first two objectives, he was largely successful: the Society publicly pledged its support for the campaign against the PRA, and raised a question in parliament to bring political attention to the issue.

It is in regards to Jabavu's third request, that the Society delay parliament until his delegation could arrive, that the Society became more fickle. Jabavu had twice requested that the APS delay the Colonial Office's decision to approve the Parliament Registration Act until his delegation had arrived in England, yet in the Society's letter to the Colonial Office of 31 October 1887, they asked for a delay to await the procurement of documentary proof, not for the arrival of an African delegation. It wrote: "[The Society] would therefore feel grateful to you if you would inform them whether, before coming to a final decision on the matter, you will wait for the detailed information which [Jabavu] has been asked to furnish to Her Majesty's Government." 59 This was in direct contradiction to Jabavu's wishes. He had explicitly written on 19 September 1887 that he considered written documentation inadequate: " $[\mathrm{I}]$ fear that the Society will be placed at a disadvantage if they are to act on a written statement of our case.... For this reason our committees are absolutely of opinion to send a delegation to the Secretary of State." 60 In its replacement of Jabavu's request to stall parliament for a delegation with a request to stall parliament for documentary evidence, we can observe the lack of control Jabavu had over the representation of his voice through the APS. 
At the same time, Jabavu did successfully intervene in imperial politics by writing to the APS: his voice was circulated to the public via articles in The Aborigines' Friend, to parliament through Alexander McArthur's question, and to the Colonial Office through the Society's letter. To be sure, the articles were heavily dominated by White voices rather than Jabavu's. For instance, an article about the Act published in the October 1887 issue of The Aborigines' Friend is ten paragraphs long. One paragraph is dedicated to paraphrasing "Mr. Tengo Jabavu" and "the objections which he and his fellow-countrymen urge against this Bill." ${ }^{1}$ By the time of publication of this article, the APS had received nine letters from Jabavu on the PRA, totalling 4,724 words, all of which were condensed into this 248 word paraphrase. Of the remaining nine paragraphs of the article, two are block quotations from Colonial Secretary Henry Holland, one is a block quotation from James Leonard, ex-attorney-general of the Cape, one is a block quotation from Clause 17 of the PRA, and half of a paragraph is dedicated to quoting Robert Meade, under-secretary of the Colonial Office. Nevertheless, despite Jabavu's extensive writing being edited down and paraphrased, and despite the obvious bias of the Society towards European voices, Jabavu's perspectives were being published and disseminated throughout England at a time when few African voices were. While it is easy to linger on the negative, on how the APS refused support for Jabavu's desire to represent himself in person and on how it interfered with Jabavu's exact words, the positive implications of Jabavu's correspondence are equally important. By corresponding with the APS, Jabavu was able to tap into an imperial knowledge network and have some, if not all, of his opinions and perspectives represented in England.

\section{Mqikela}

My second case study, Mqikela, was born circa 1841 to Faku, paramount chief of the Mpondo kingdom. Mqikela was not Faku's eldest son, but his mother was the highest ranked of Faku's wives, and so Mqikela became the traditional heir to the Paramountcy. This caused conflict between Mqikela and his elder brother, and so Faku divided Pondoland into a western district and an eastern district. Mqikela was to inherit eastern Pondoland, and his brother was to inherent western Pondoland. Mqikela succeeded to the throne of eastern Pondoland when Faku died in $1867 .{ }^{62}$ Following the annexation of British Kaffraria to the Cape in 1866 there were four independent African polities remaining between the Cape and Natal: three Xhosa kingdoms (the Thembu of 
Thembuland, the Mfengu of Fingoland and the Mpondo of Pondoland) and the Griqua of Griqualand East. Thembuland, Fingoland and Griqualand East were each annexed to the Cape following the Ninth Frontier War (1877-78), yet the Mpondo had never engaged in hostilities with any of the settler colonies and so there was no political justification to annex Pondoland. The Mpondo did, however, engage in large-scale cattle trading with Natal, and many of these cattle were paid for in firearms, so that Pondoland had become a gateway for firearms into the interior. Citing the Mpondo trade routes as a threat to colonial security, Governor of the Cape Colony and High Commissioner for Southern Africa Sir Henry Bartle Frere annexed the Mpondo trading port of Port St John's to the Cape in $1878 .{ }^{63}$ Additionally, the Xesibe, a small chiefdom within Pondoland that had been clashing with the Mpondo for decades, had in 1874 requested British protection, and so Bartle Frere also annexed Xesibeland to the Cape in $1878{ }^{64}$ From 1878 onwards Mqikela had repeatedly petitioned the Cape to open negotiations over the return of his land and the Cape had shown interest in opening such negotiations, but only for monetary compensation. Mqikela considered the return of his land to be the only acceptable compensation, and so he and the Cape government arrived at an impasse. To overcome this impasse, Mqikela began to plan a delegation to England to petition the imperial government to return his land on the Cape's behalf. $^{65}$

The historiography on Cape-Mpondo conflict over Port St John's and Xesibeland has predominantly focused on the role of Europeans in Mqikela's court. Mfengu leaders had employed Europeans as secretaries and diplomats since 1844, when Faku employed Methodist missionaries from nearby his capital. Yet Mqikela grew impatient with his Methodist agents in 1880 when they refused to send letters to Bartle Frere criticizing his confederation scheme, citing the policy of their mission to avoid politics. ${ }^{66}$ From then on Mqikela employed traders and lawyers as his agents, beginning with H.W. Welborne in 1881. Welborne was a lawyer in Kokstad and, as the attorney of several cattle-traders in Natal, was actively interested in challenging British intervention in the lucrative Mpondo cattle trade. He was dismissed in 1882 due to mismanagement of Mpondo resources, and was replaced by a trader named Hamilton MacNicholas. MacNicholas and his business partner William Bouverie were also actively interested in preventing British intervention in their trading activities, and enthusiastically assisted Mqikela in resisting British confederation. ${ }^{67}$ In William 
Beinart's study of the relationships between colonial traders and the Mpondo chieftaincy, he argues that MacNicholas and Bouverie were not neutral messengers between Mqikela and the Cape or Britain. Rather, Beinart illustrates that MacNicholas and Bouverie had substantial economic interests in preventing Mpondoland from coming under Cape or British rule. As such, Beinart argues that MacNicholas and Bouverie actively sought to intervene in Mpondo politics to drive a wedge between Mqikela and the Cape, and possibly to foment a war. ${ }^{68}$ The very idea of writing to the APS is attributed to Bouverie and MacNicholas. According to Beinart, "they were responsible for a new initiative - an attempt to convert the Aborigines' Protection Society to the Mpondo cause," and it was only through Bouverie and MacNicholas that Mqikela was able to connect with the APS. ${ }^{69}$ There is some truth to this: both of their names appear as witnesses to the letters written by Mqikela, and it is likely that they helped translate and transcribe the letters. Moreover, Bouverie and MacNicholas both maintained their own personal correspondence with the APS and Bouverie's father, a respected admiral in London, was involved with the APS. It is therefore inescapable that Bouverie and MacNicholas played a significant role in connecting Mpondoland and the APS. Yet, as I will show, there are very substantial differences between Mqikela's letters to the APS and those of Bouverie and MacNicholas, and these differences demonstrate that Mqikela engaged with the APS in different ways and for different reasons than Bouverie and MacNicholas.

It was within the context of his planned delegation that Mqikela wrote four letters to the APS across 1883 and 1884. Mqikela made two specific requests. First, in his letter of 1 August 1883, he asked for a loan to assist in sending a delegation to England.

I therefore... make an appeal to your Society to assist me with funds for the purpose of sending the above mentioned delegation so that what I complain of will be properly represented. I do not solicit as a gift, but as a loan which I will repay as soon as I can collect sufficient cattle. ${ }^{70}$

Second, he requested the APS convince Colonial Secretary Lord Derby to receive the Mpondo delegation. Mqikela had previously been in direct correspondence with the Colonial Office regarding his case, and in his letter to the APS dated 8 February 1884 he informed the Society of a response he had received from the Colonial Office which indicated that "Her Majesty's government will not receive any deputation from me."71 
Consequently, Mqikela asked the APS to raise a question in parliament to convince Derby to change his mind: "I should be very thankful if your Society could bring the matter of Lord Derby's refusal to receive my deputation before the house of parliament."72

When the Society first received Mqikela's letters, it supported his case for the return of his land. The Society held a meeting on 18 October 1883 to discuss Mqikela's case, after which a summary of Mqikela's grievances against the annexation of Xesibeland and Port St John's, along with the Society's sympathies, were published in The Times. ${ }^{73}$ A full transcript of Mqikela's letter of 1 August 1883 was also published in the March 1884 issue of The Aborigines' Friend, ${ }^{74}$ and his letter of 8 February 1884 was forwarded by the APS to the Colonial Office. ${ }^{75}$ The Society's support did not include providing Mqikela with the funding he requested, as it felt that a delegation would not be able to change anything. It told Mqikela so, but it also sent a letter to the Colonial Secretary Lord Derby dated 28 April 1884, declaring that if, despite the Society's advice against a delegation, Mqikela "came to a different conclusion and decided to send a delegation to England, the Society would render it every assistance in its power."76 A question in parliament on the issue of returning the annexed territories to Mqikela was also raised by William McArthur, Alexander McArthur's son, on 12 August $1884 .^{77}$ These publications, letter and question in parliament illustrate Mqikela's successful intervention in imperial politics through writing to the APS, although his intervention did not come with the funding he had hoped for.

From that point onwards, however, the Society changed its position and supported the total annexation of Pondoland. Following its letter to the Colonial Office of 28 April 1884, the Society made only two more references to Pondoland. The first, an article published in the December 1884 issue of The Aborigines' Friend, was decidedly dismissive of Mqikela. In his letter of 12 July 1884, Mqikela had challenged various representations made of him by Olley Oxland, the British Resident in Pondoland. First, Mqikela challenged a claim that Hamilton McNicholas, his advisor, had pledged the APS's support for his delegation. Second, he challenged a claim that he was a passive agent controlled by his White advisors. Third, he challenged a claim that his other chiefs did not support his delegation. ${ }^{78}$ The Aborigines' Friend article did not reference any of this. Instead, it only referenced the last section of Mqikela's letter, 
where he implied the possibility of giving up his plan for a delegation and turning to violence: "Do not, therefore, be surprised if I say I quite despair of ever obtaining my rights by peaceful means."79 The Society quoted these grim expressions, and concluded that the affairs in Pondoland had to be settled quickly in order to avoid conflict. What is more, the Society asserted that "the case of Umquikela is one which urgently calls for settlement on the lines recommended by the Secretary of Native Affairs at the Cape... an attempt should be made to satisfy him with a money payment." 80 The APS no longer supported Mqikela's claims to Xesibeland and Port St John's. Instead, it now supported the Cape's policy of offering monetary compensation for annexation.

We can only speculate on why the APS changed its policy towards Pondoland, but an important factor appears to be that Mqikela become increasingly suggestive of moving towards violent resistance, and it seems likely that the Society wanted to distance itself from Mqikela's suggestions of violence. There are three potential reasons for the APS wanted to distance itself from violence: to appease Quaker supporters who condemned violence, to appease imperial officials who condemned expensive imperial interventions, and to appease jingoists who would be aghast if the APS seemed to condone violence against settlers. From its earliest origins, the APS had been closely tied to the British Society of Friends. The Quaker prerogative to perform the testimony of peace through personal action has led Quakerism to be closely identified with a strong pacifist ideology. ${ }^{81}$ As a consequence, Quakers took up important leadership positions in many of the social movements of the eighteenth and nineteenth centuries, including both the antislavery movement and the protection of Indigenous peoples, and Quakers made up a strong majority of the APS's financial backers: an estimate from 1877 held that 210 of 263 financers were Quakers. ${ }^{82}$ Recognizing its financial dependence upon the donations and dues of its primarily pacifist supporters, the APS was careful to ensure that it distanced itself from anything that could be "suspected of sympathising with the measures of insurrectionary violence." 83

The APS was just as careful to avoid alienating imperial officials who had no intention of spending yet more money on colonial warfare. In 1884, the British government was already quite unhappy with the extent of its presence in South Africa. Basutoland had been devolved from imperial control to the Cape back in 1871, and yet 
the disastrous Basuto Gun War (1880-81) had resulted in Basutoland coming back under imperial rule in 1884 . The Zulu civil war (1883-88) that followed the Ulundi Settlement had, by 1884, resulted in Boer claims to a New Republic in Zululand and was looking more and more likely to require significant imperial intervention. Boer encroachments in Bechuanaland between 1881-84 were also pulling the empire in, and by the next year the Bechuanaland Protectorate would be officially proclaimed. The last thing the Colonial Office wanted was a colonial war in Pondoland that might also require imperial intervention, and the APS was likely highly cognizant of this. Only three years later, for instance, in the context of the Zulu civil war, the APS wrote to Harriete Colenso that "it would be fatal to us if the impression got abroad that one so closely associated with the Society as you have been had stirred up the Zulus to hopeless resistance." ${ }^{84}$ Furthermore, Heartfield suggests that the APS worked hard to not be identified as anticolonial, as they were aware that "protecting the natives clearly put it at odds with the mainstream of Empire jingoism." ${ }^{\text {"T5 }}$ The APS therefore was careful to avoid any stance which could be perceived as supportive of rebellion against the colonies.

Throughout Mqikela's letters, however, he made threats of violence that became stronger over time. In Mqikela's first letter to the APS, dated 1 August 1883, he asserted that he wished to resolve his disputes peacefully and would only resort to violence if the Cape government forced him to by refusing to negotiate the return of his territory.

I am an old man now and wish, if possible, to pass the remainder of my days in peace — but it appears to me - unless I can with your assistance send a delegation immediately to England to get my grievances addressed - that I shall be forced by the Cape Government into war. ${ }^{86}$

This statement made a hint of a possible move towards violence, but emphatically prioritized a peaceful resolution. Mqikela made a similar, yet stronger, suggestion of violence six months later, in his letter of 8 February 1884: "It would seem as if the Cape government are desirous of forcing me to resort to arms to obtain the restoration of my country-I will however be entirely guided by the advice I receive from your Society." ${ }^{\text {"87 }}$ Mqikela threatened violence just as in his first letter, and again emphasized his desire for a peaceful resolution, but also put more expression into the possibility of 
a violent rebellion. This pattern of increasing threats of violence culminated with his letter of 12 July 1884 , in which he proclaimed his despair at his inability to obtain a peaceful resolution and lamented the seeming inevitability of violence: "I have been told that 'the pen is mightier than the sword,' but I do not think it has been so in my case... I quite despair of ever obtaining my rights by peaceful means." 88 That this ominous portion of Mqikela's 12 July letter was the only part of this letter published in The Aborigines' Friend's December 1884 issue is telling: it shows us that Mqikela's move closer to violence was not lost on the APS. Since we know that the Society was cautious about being associated with violence lest it alienate its subscribers, the Colonial Office, and jingoists in general, it is likely that this caution led the Society to turn against Mqikela and cut off the access it previously provided him to imperial politics.

As with Jabavu, Mqikela did not achieve all of his goals in writing to the APS. Funding for his delegation was refused, and the APS eventually gave up its support for him entirely. Yet just as I suggested in Jabavu's case, it is important that we should not be so preoccupied with the negative aspects of Mqikela's experience with the APS that we dismiss the positive aspects. As with Jabavu, Mqikela's voice was transmitted to the British public through The Times and The Aborigines' Friend, to parliament through William McArthur, and to the Colonial Office through the APS's letter. While Mqikela could not control exactly how the APS treated his letters, we can observe that writing to the APS did afford Mqikela a means of intervening in imperial politics.

\section{Moroka}

My third case study, Samuel Moroka, wrote six letters to the APS from 1883 to 1884. Samuel was born circa 1840 to Moroka II, chief of the Thaba Nchu Barolong. Samuel was the third son by Moroka II's great wife, Moilana, and so was the traditional heir to the throne. Samuel's father sent him to be educated in Cape Town, and between 1861 and 1865 Governor George Grey sponsored Samuel to study at St. Augustine's College in Canterbury, England, where he converted to Christianity. ${ }^{89}$ Samuel's conversion was problematic for several reasons. The Barolong paramount chief was to be the link between the ancestral world and the physical world, and Samuel had supposedly severed that link by converting to Christianity. Polygamy was also a customary practice among chiefs as a measure to assure a continuing line of succession, yet as a Christian 
Samuel refused to marry more than once. ${ }^{90}$ As such, Moroka II nominated his elder son, Tshipinare, as his successor. Samuel Moroka and Tshipinare both asserted their respective claims upon Moroka II's death, and the Orange Free State grew nervous of a succession dispute erupting into a violent civil war that would draw the attention of the British imperial government to the Free State. Johannes Brand, president of the Free State, intervened, choosing Tshipinare as the new ruler of Thaba Nchu and banishing Samuel Moroka. ${ }^{91}$ Samuel Moroka refused to abandon his claim to power, and embarked on a decade-long mission to retake Thaba Nchu. After being refused assistance from the BaSotho and from the Cape Colony, he travelled to England to request imperial assistance, but little help was forthcoming. On the morning of 10 July 1884 Samuel returned to Thaba Nchu and executed Tshipinare and his family, seizing the chieftainship in a violent coup. President Brand sent a commando the very next day, capturing Samuel and annexing Thaba Nchu to the Free State on 11 July. ${ }^{92}$ Brand tried to convict Samuel for the capital offense of murder, but the court determined that Tshipinare's murder had not been committed on Free State soil at the time and so could not convict him of the capital offence. Samuel was once again banished, and he and his followers took refuge with the BaSotho. ${ }^{93}$

Samuel's fight for the chieftainship was partly an African-Boer conflict between the Barolong and the Free State, but, as I will go on to show, it was also partly an internal Barolong conflict between Samuel's vision of adaptation through subjection to the British Empire and Tshipinare's vision of adaptation through subjection to the Free State. Prior to Samuel's return from England in 1865, Christianity in Thaba Nchu was synonymous with Wesleyan Methodism. Methodist missionaries had been active in the region since 1823 and had deep connections with the Free State. ${ }^{94}$ Tshipinare himself was educated at a Methodist school at Graham's Town, and he found no difficulty in reconciling his education with his father's policy of independence alongside the Free State. ${ }^{95}$ Samuel, on the other, was educated at Anglican schools in Cape Town and Canterbury, and during his education he came to see himself less as an independent Barolong than as a British subject. ${ }^{96}$ Indeed, when Samuel returned to Thaba Nchu in 1865 he came partly as an imperial agent, with a promise to build an Anglican church and establish the English church in his chiefdom. ${ }^{97}$ Thus, when Samuel travelled to England in 1884 to request imperial assistance, he did so not as a desperate act of last resort, but as a manifestation of his sincere belief in the benevolence of the British 
Empire. But how did he manage to carry out this mission to England? Historians have been fairly unconcerned about the fact that Samuel went to London and "argued before the fifteenth Earl of Derby," 98 but obtaining a meeting with the Secretary of State for the Colonies was not an easy feat. Samuel's imperial identity may have gotten him on the boat to England, but it didn't get him into Derby's office. That is where Samuel's correspondence with the Aborigines' Protection Society comes into play.

It was during his trip to England that Samuel Moroka sent four letters to the APS. He made three requests of the Society. First, on 26 December 1883, he forwarded to the APS drafts of some sort, likely letters, petitions or speeches, which he asked the APS to help edit and improve: "Enclosed I beg to hand to you for your perusal two documents which when corrected and altered I intend to send in proper order.... If the enclosed are not to your wish kindly send me a draft and I will at once obey your instructions." 99 Second, on 1 January 1884, he asked the APS to help him receive an audience with Colonial Secretary Lord Derby, so that he could represent his claim to Thaba Nchu personally: "If you also by your own influence as well as through Captain Wills can obtain that purpose, the consul [Lord Derby] will see me again."100 Third, on 22 January 1884, he asked the APS to convince Richard Southey, ex-colonial secretary and Cape politician, to support his claim, "because he is much respected in the Free State." 101

Prior to receiving Samuel Moroka's letters, the Society had only mentioned Thaba Nchu in passing, always in the context of Moroka II's conflicts with the BaSotho in the 1850s. After it received his letters, an article about Samuel Moroka and his case for the chieftaincy of Thaba Nchu appeared in The Aborigines' Friend in March 1884, demonstrating the Society's willingness to support his cause. Unfortunately, there is little evidence concerning how many of Samuel Moroka's three requests were successful. We cannot know whether his request for assistance editing his petitions was agreed to, and it is hard to tell if the Society succeeded in arranging a meeting with Lord Derby. However, the March 1884 issue of The Aborigines' Friend does tell us several things. It tells us that the APS secured at least two meetings between Samuel Moroka and prominent members of parliament. The first meeting was with Robert Fowler, and the second with Wilfred Lawson: 
We may add that both the Chief [Samuel Moroka] and his faithful councillor, William Sekue, have been received by the Lord Mayor [Robert Fowler] at the Mansion House... and a meeting, presided over by Sir Wilfred Lawson, M.P., was held on Tuesday, February 26th, to express sympathy with him. ${ }^{102}$

Both Fowler and Lawson were affiliated with the Society, Fowler as a member and Lawson as a recurring collaborator, ${ }^{103}$ making it likely that these meetings were secured by the Society's influence. There is also some evidence suggesting that the APS at least attempted to arrange a meeting with Lord Derby. In a letter from Richard Southey to the APS dated 24 January 1884, Southey mentioned an upcoming meeting between Lord Derby and an unnamed delegation:

The Lord Mayor [Robert Fowler] has just received the enclosed letter from Lord Derby. Tomorrow at 3 will suit him, if you can get the delegation together in time. In any case kindly write to Lord Derby your decision and let the Lord Mayor know. ${ }^{104}$

Southey's letter does not mention who is on the delegation, but since this letter was written while Samuel Moroka was in London, it is reasonable to suppose that Samuel may have been included. Moreover, the letter only tells us that a meeting with Lord Derby was planned, not whether this meeting actually took place, but that in itself is something. And the fact that Richard Southey was writing to the APS about Samuel Moroka also suggests that the APS talked to Southey on his behalf.

In this regard, it is relatively safe to conclude that for Moroka, corresponding with the APS was an entirely successful strategy for intervening in imperial politics, and in this he is different from Jabavu and Mqikela. Jabavu and Mqikela desired assistance in sending delegations, and instead only obtained assistance in transmitting their voices to the public, to parliament and to the Colonial Office. Samuel Moroka's voice was transmitted to the public through The Aborigines' Friend, but he also received the support he requested for his delegation. One possible explanation for this is that the APS only wanted to support public appearances of Africans who could perform a certain style of "civilization," since Moroka's status as a graduate of an English university distinguished him among many of the APS's African correspondents. On the other hand, it did not particularly distinguish him from Jabavu, 
who had matriculated from the University of Cape Town. Rather, I would argue that what really distinguished Moroka from the other correspondents was the alternative funding he was able to obtain. I cannot find any information on how Moroka got himself to England, but he was the only one who did, indicating that he had some source of funding that the others did not. As Swaisland has detailed, the Society was not a wealthy one. "Most members of the APS and those closely associated with them were middle class and of the middle and lower strata of it."105 Surviving on the donations of its lower-middle class subscribers, the APS likely did not have the money to be funding every delegation that asked for help. While Samuel Moroka's status as universityeducated and Christian may have influenced his experience with the APS, his ability to travel to England without Society funding probably played a bigger role.

From these three case studies we can observe that although Jabavu, Mqikela, Samuel Moroka all wrote to gain the Society's support for delegations, there is little overlap in the specific forms they requested this support to take. Indeed, there are only two requests that appear more than once. First, Mqikela and Jabavu both requested the APS to raise questions in parliament. Second, Mqikela and Moroka both requested the APS to arrange meetings between themselves and the Colonial Secretary. Otherwise, Mqikela was alone is requesting funding, Jabavu was alone in requesting the APS to stall parliament, and Moroka was alone in requesting the APS to edit his petitions and to talk to individual politicians for him. This variety shows that even though seeking support for delegations is a common theme in the letters from Africans to the APS, this commonality does not equate with a monolithic conceptualization of the APS' relation to African politics. Instead, the APS' utility was interpreted by these correspondents according to their individual needs at specific moments in time. All of the letters discussed in this paper are historically significant, for they represent attempts by select Africans to intervene in metropolitan politics through the APS' correspondence network. Yet they also take one step further by seeking to represent themselves in person, rather than asking to be represented by the Society. An important question remains: Why did these correspondents request this sort of aid from the APS in the first place?

Travelling to England to speak directly to the British monarch and the Colonial Office was a common strategy of African leaders in the second half of the nineteenth 
century. King Sechele of the Kwena Tswana embarked on a mission to England in 1853 to request assistance in resisting the Afrikaners of the South African Republic. King Moshoeshoe of the BaSotho sent a delegation to England in 1869 to negotiate an alliance. Cetshwayo, the deposed king of the Zulu, travelled to England in 1882 to negotiate his return to Zululand. King Lobengula of the Ndebele sent a delegation to England in 1889 and in 1891 to protest the granting of land rights to the Rhodes mining syndicate. Nine Swazi delegates were sent to England by Queen Labotsibeni in 1894 to request protection from the South African Republic. Finally, three Tswana chiefs, Khama, Sebele and Bathoen, travelled to England in 1895 to request protection from annexation to Rhodesia. ${ }^{106}$ It is in this greater context of African delegations to England that the correspondents requested assistance from the Society to send their own delegations.

Yet supporting African delegations was not an official object of the Society, and historians have suggested that the Society did not support such delegations wholeheartedly. Brian Willan argued that the APS was against the very notion of African delegations, since "a group of highly educated and articulate Africans proving themselves eminently capable of presenting their case without the Society's assistance and guidance" threatened "the Society's entire raison d'etre as a mediator between the 'native races' and the imperial government."107 Zoe Laidlaw challenges Willan's argument by identifying many delegations that were, indeed, supported by the APS. Yet Laidlaw also problematizes the Society's support for delegations by arguing that "in its enthusiasm for indigenous informants, the APS rated their emotional pull and 'authenticity' over the information and critical insights they provided."108 In other words, the APS sought to use delegates' voices to further its own interests rather than to empower the delegates themselves. Gwilym Colenso further problematizes APS support for delegations by suggesting that such support negatively impacted the very delegations they were supposedly aiding:

It may be argued that the APS did provide some support for deputations. During their mission to England in 1889, the Ndebele envoys were guests of honour at a special breakfast hosted by the APS at the Westminster Place Hotel. But, at best, this could be counted as a poor second to having strong representation on the occasions that really 
counted. At worst, it could be argued that, along with the royal audience granted to these envoys, this breakfast was yet another ceremonial diversion from the concrete objectives and real political mission of the delegates which would be determined at meetings with the minister and officials in the Colonial Office. ${ }^{109}$

The disparity between Willan's, Laidlaw's and Colenso's analyses of the APS' relationship with deputation can be somewhat explained by the different time periods they were writing about. Laidlaw was writing about the 1850s, when Thomas Hodgkin was secretary. Colenso wrote of the late 1880s and 1890s, Henry Fox Bourne's period of tenure. And Willan wrote of an APS led by John Harris. Not only did each of these secretaries imprint the APS with their own beliefs and personalities, but they each operated in a different period of the British Empire; perceptions of Indigenous people certainly changed substantially between 1850 and 1909, and even more so as the Society morphed into the ASAPS. It is beyond the scope of this paper to compare and contrast the APS' attitudes towards African deputations from secretary to secretary and era to era. Suffice to say that, from the 1850s to the 1910s, the APS (and ASAPS) could not reliably be counted upon to support a deputation. What, then, can be made of Jabavu's, Mqikela's and Moroka's shared experience of seeking APS support for deputations?

I offer three further arguments based on the three case studies presented. First, whereas Willan, Laidlaw and Colenso question the nature and impact of APS attitudes towards delegations, I argue that it is equally important to question why African delegations sought support from the APS in the first place. As Colenso demonstrates, delegations to England were subject to extensive manipulation and interference by the Colonial Office. These delegations were mostly funded by the Colonial Office: a substantial budget was dedicated to funding travel, hospitality and even sight-seeing arrangements. In return, the Colonial Office would insist upon its prerogative to choose the delegations' interpreters, to choose whom the delegation could meet, and control the level of publicity the delegation could receive. ${ }^{110}$ Furthermore, if delegations refused to accept a government-provided interpreter, the Colonial Office would simply refuse to arrange meetings with the delegations. This is exactly what happened to the BaSotho delegations in 1869 and 1907 and the Swazi delegation in $1894 .{ }^{111}$ In this 
context, I suggest that requesting aid from the Aborigines' Protection Society represented an attempt to side-step government influence over how the Black correspondents' voices were represented in England. Hints of this motivation are visible across all three of my case studies. Jabavu faced a stonewalling Colonial Office that would not consider his request to veto the PRA, and he approached the APS to side-step the Colonial Office and influence parliament directly. Mqikela faced a Colonial Office that refused to receive an Mpondo deputation, and he approached the APS to change its mind. And Samuel Moroka expressed the difficulty he was having obtaining a meeting with the Colonial Office, and he approached the APS for help in arranging a meeting. From this perspective we can observe that, regardless of whether APS support was offered and effective, the very act of writing to them and requesting their support was a strategic ploy for resisting imperial control based upon a nuanced understanding of the barriers present in imperial politics.

The second argument I offer is that attempted-yet-failed delegations are of equal importance to the delegations that actually took place. Laidlaw argues that studying the language of the delegates hosted by the APS - paying attention to how they strategically performed a hybrid identity of civilized authority and traditional authenticity in order to gain the Society's and the British public's attention-is important because it "illuminates both the workings of colonialism and those who objected to it."112 I wholeheartedly agree, and I seek to expand beyond Laidlaw's treatment of delegations to England as a singular moment: she attends to the discourses of civility and authenticity at the moment of the delegation, yet does not attend to how those delegations came to occur in the first place. This paper has shown that sending a delegation through the APS was not a singular moment, but the final stage of a longer process of correspondence that differed for each correspondent. As such, the letters negotiating and leading up to delegations are just as important for illuminating "the workings of colonialism and those who objected to it." Moreover, only one of the three planned delegations I mention ever took place, indicating that a focus on delegations as they happened in England excludes many attempted-yet-failed delegations.

The third, and most important, argument I offer is that the APS' textual archive reveals a much greater extent of African engagement than does the public archive of delegations and meetings. True, the APS only supported one of three attempted 
delegations, but it empowered its correspondents in many other ways. It published Jabavu's, Mqikela's and Samuel Moroka's letters and perspectives in The Aborigines' Friend and in The Times. It wrote letters to the Colonial Office based on the correspondents' information. And it raised questions in parliament based on the correspondents' letters. In publishing their voices in journals and newspapers, the APS afforded Jabavu, Mqikela and Samuel Moroka space to represent themselves in public imperial discourses. In sending letters to the Colonial Office and raising questions in parliament on their behalf, the APS empowered Jabavu, Mqikela and Samuel Moroka to intervene in imperial politics directly.

While the Aborigines' Protection Society was largely unsuccessful in its mission to expand a benevolent British Empire and ameliorate Indigenous-settler relations throughout the colonies, it would be irresponsible to dismiss the historical significance of the APS. While it failed to fulfill its political mission, it succeeded in circulating knowledge from the colonies to the metropole and back, and this knowledge circulation is very historically significant. This paper represents what I hope will only be the beginning of research into the APS' correspondence network, yet the insights expressed in this paper provide the necessary foundation for further critical analysis. I have provided evidence that Africans strategically engaged with the APS as an anticolonial network in various and contextually specific ways. And I have provided evidence that African knowledge was positively received and acted upon by the APS, demonstrating that the APS did, to an extent, operate as an anticolonial network, affording these correspondents a means of intervening in imperial discourses and politics from the far edges of the empire.

For correspondence: darren.reid.20@ucl.ac.uk.

\section{Notes}


${ }^{1}$ Zoë Laidlaw, “Heathens, Slaves, and Aborigines: Thomas Hodgkin's critique of missions and anti-slavery," History Workshop Journal 64/1 (2007): 136.

2 Those 9,605 letters are divided into fonds according to who was secretary of the Society at the time the letters were received, so that there is a Thomas Hodgkin fonds covering letters from 1831-65, a Frederick Chesson fonds covering 1866-88, a Henry Fox-Bourne fonds covering 1888-1909, and a miscellaneous fonds. The vast majority of the letters in the collection, 6,773 or 70 percent of the total, are in the Frederick Chesson fonds. This paper focuses on the Chesson fonds, as they are far richer than the others for in-depth analysis.

${ }^{3}$ Transcripts and photographs of many of these letters, including all referenced in this paper, can be found at https://aps.darrenreid.ca/.

${ }^{4}$ For example, Rachel Whitehead dedicates an article to deciphering how the APS could have entered into an "incongruous alliance" with the settlers of Rhodesia in the early twentieth century, revealing the implicit assumption that allying with settlers was abnormal: Rachael Whitehead, “The Aborigines' Protection Society and White Settlers in Rhodesia, 1889-1930," Collected Seminar Papers, Institute of Commonwealth Studies, 1973.

5 James Heartfield, The Aborigines' Protection Society: Humanitarian imperialism in Australia, New Zealand, Fiji, Canada, South Africa, and the Congo, 1836-1909 (New York: Columbia University Press, 2011), 61.

${ }^{6}$ S.E. Atkinson to Chesson, 5 April 1876, Bodleian Libraries, APS papers, MSS. Brit. Emp. S. 18, C125/48.

${ }^{7}$ Throughout this paper I refer to regions by their contemporaneous place names, specifically the place names used in British parlance. Pondoland, for instance, may more appropriately be called Mpondoland or EmaMpondweni, but I have opted to use the spellings that appear in the primary sources themselves.

${ }^{8}$ Darren Reid, 'Shadrach Boyce Mama and the 'Kaffir Depot': Navigating imperial networks to agitate against the forced removal of Xhosa women and children from Cape Town, May-December 1879," South African Historical Journal 72/4 (2020): 561-78.

${ }^{9}$ André Odendaal, Vukani bantu! The beginnings of Black protest politics in South Africa to 1912 (Cape Town: David Philip, 1984), 3. 
${ }^{10}$ Thomas Karis and Gwendolen Carter, eds., From Protest to Challenge: A documentary history of African politics in South Africa, 1882-1964, Volume 1: Protest and Hope, 1882-1934 (Stanford: Hoover Institution Press, 1972), 3-8. ${ }^{11}$ See Vukile Khumalo, "Ekukhanyeni Letter-writers: A historical inquiry into epistolary networks and political imagination in KwaZulu-Natal, South Africa," in Africa's Hidden Histories: Everyday literacy and making the self, edited by Karin Barber (Bloomington: Indiana University Press, 2006), 113-42; Lize Kriel, “To My Dear Minister: Official letters of African Wesleyan evangelists in the late $19^{\text {th }}$-century Transvaal," in Written Culture in a Colonial Context: Africa and the Americas, 15001900, edited by Adrien Delmas and Nigel Penn (Leiden: Brill, 2012), 243-58. ${ }^{12}$ For a discussion of epistolary literacy, see Susan Whyman, The Pen and the People: English letter writers 1660-1800 (Oxford: Oxford University Press, 2009), 1-14. For a discussion of other types of literacies in the Pacific context, see Tracy Banivanua Mar, "Imperial Literacy and Indigenous Rights: Tracing transoceanic circuits of a modern discourse," Aboriginal History 37 (2013): 1-28.

${ }^{13}$ A. Herbert to Frederick Chesson, 6 February 1880, C143/156.

${ }^{14}$ Henry Charles Swaisland, “The Aborigines' Protection Society and British Southern and West Africa" (PhD thesis, University of Oxford, 1968), v.

15 These territories include Fingoland, Thembuland, Griqualand East, Griqualand West, Zululand, Basutoland, Bechuanaland, Xesibeland, St John's Port and the Transvaal.

${ }^{16}$ This barrage included ninety-nine articles on South Africa in its journal The Aborigines' Friend, at least thirty articles in The Times, and dozens of letters on South Africa directly to the Colonial Office and numerous questions raised in parliament through its allies in the Liberal party.

${ }^{17}$ Heartfield, The Aborigines' Protection Society, 243.

${ }^{18}$ Aborigines' Protection Society, "South Africa and the War in Zululand," The Aborigines' Friend (June 1879): 124, Gale Digital Collections, Nineteenth Century UK Periodicals.

${ }^{19}$ APS, "South Africa and the War in Zululand," 124.

${ }^{20}$ Heartfield, The Aborigines' Protection Society, 43-54. 
${ }^{21}$ Brian Willan, “The Anti-Slavery and Aborigines' Protection Society and the South African Natives' Land Act of 1913," The Journal of African History 20/1 (1979): 83102.

${ }^{22}$ Catherine Burns, "The Letters of Louisa Mvemve," in Africa's Hidden Histories, ed. Barber, 78-112.

${ }^{23}$ Khumalo, “Ekukhanyeni Letter-writers," in Africa's Hidden Histories, ed. Barber, $113-42$.

${ }^{24}$ Keith Breckenridge, "Reasons for Writing: African Working-Class Letter-Writing in Early-Twentieth-Century South Africa," in Africa's Hidden Histories, ed. Barber, $143-54$.

${ }^{25}$ Kriel, “To My Dear Minister," in Written Culture in a Colonial Context, ed. Delmas and Penn, 243-58.

${ }^{26}$ Swaisland, "The Aborigines' Protection Society," 424-29.

${ }^{27}$ Ronald Rainger, "Philanthropy and Science in the 1830's: The British and Foreign Aborigines' Protection Society," Man 14/4 (1980): 702-17.

${ }^{28}$ Roderick Mitcham, "Geographies of Global Humanitarianism: The Anti-Slavery Society and the Aborigines' Protection Society, 1884-1933" (PhD thesis, University of London, 2001), 32.

${ }^{29}$ Heartfield, The Aborigines' Protection Society, 41.

${ }^{30}$ Elizabeth Elbourne, "Indigenous Peoples and Imperial Networks in the Early Nineteenth Century: The politics of knowledge," in Rediscovering the British World, edited by Phillip Buckner and R. Douglas Francis (Calgary: University of Calgary Press, 2005), 78.

${ }^{31}$ Zoë Laidlaw, "Indigenous Interlocutors: Networks of imperial protest and humanitarianism in the mid-nineteenth century," in Indigenous Networks: Mobility Connections and Exchange, edited by Jane Carey and Jane Lydon (New York: Routledge, 2014), 115-19.

${ }^{32}$ Laidlaw's upcoming monograph with Cambridge University Press, Protecting the Empire's Humanity: Thomas Hodgkin and British colonial activism, 1830-1870, expands considerably on the APS's relationships with individual Indigenous correspondents and their colonial allies - including, but going well beyond, deputations. 
${ }^{33}$ Aborigines' Protection Society, The First Annual Report of the Aborigines' Protection Society, Presented at the Meeting in Exeter Hall, May 6 ${ }^{\text {th }}, 1838$ (London: W. Ball, Aldine Chambers, 1838), 11.

${ }^{34}$ Leonard Diniso Ngcongco, “John Tengo Jabavu 1859-1921," in Christopher C. Saunders, ed., Black Leaders in Southern African History (London: Heinemann Educational Books, 1979), 143-46.

${ }^{35}$ Les Switzer, South Africa's Alternative Press: Voices of protest and resistance, 1880s-1960s (Cambridge: Cambridge University Press, 1997), 60-66; Siyasanga Tyali, “Ambiguities of a Decolonizating Press Culture: On South Africa's Imvo Zabantsundu (Native Opinion)," South African Journal of African Languages 38/3 (2018): 307.

${ }^{36}$ Cape of Good Hope, Census of the Colony of the Cape of Good Hope, 1865 (Saul Solomon and Co., 1866), 11.

${ }^{37}$ Cape of Good Hope, Results of a Census of the Colony of the Cape of Good Hope, as on the Night of Sunday, the 5th April, 1891 (W. A. Richards and Sons, 1892), 3. ${ }^{38}$ Cape of Good Hope, Statutes of the Cape of Good Hope Passed by the Seventh Parliament during Sessions 1884-1888 (W. A. Richards \& Sons: 1889), 390.

${ }^{39}$ Cape of Good Hope, Statutes of the Cape of Good Hope, 1884-1888, 394.

${ }^{40}$ D.R. Edgecombe, “The Non-Racial Franchise in Cape Politics, 1853-1910," Kleio 10/1-2 (1978): 28-30.

${ }^{41}$ Julie Evans, Patricia Grimshaw and David Philips, Equal Subjects, Unequal Rights: Indigenous peoples in British settler colonies, 1830-1910 (Manchester: Manchester University Press, 2003), 157-92.

${ }^{42}$ Leonard Diniso Ngcongco, “Imvo Zabantsundu and Cape 'Native' Policy 18841902" (MA thesis, University of South Africa, 1974), 51-53.

${ }^{43}$ Edgecombe, "The Non-Racial Franchise in Cape Politics," 37.

${ }^{44}$ Edgecombe, "The Non-Racial Franchise in Cape Politics," 23; Ngcongco, "Imvo Zabantsundu and Cape 'Native' Policy," 56.

${ }^{45}$ Khwezi Mkhize, “'To See Us As We See Ourselves’: John Tengo Jabavu and the politics of the Black periodical," Journal of Southern African Studies 44/3 (2018): 423.

${ }^{46}$ Edgecombe, "The Non-Racial Franchise in Cape Politics," 29-30. 
${ }^{47}$ Petition to Queen Victoria from the Native Inhabitants of the Location of Oxkraal, July 1887, in From Protest to Challenge: A documentary history of African politics in South Africa, 1882-1990, vol. I, edited by Sheridan Johns, Thomas Karis and Gail Gerhart (Auckland Park: Jacana, 2014), 15-16.

${ }^{48}$ See Mkhize, “"To See Us As We See Ourselves,"”; Tyali, “Ambiguities of a Decolonising Press Culture," 303-9.

${ }^{49}$ John Tengo Jabavu to Chesson, 28 March 1887, APS papers, C139/10.

${ }^{50}$ Jabavu to Chesson, 19 September 1887, APS papers, C139/18.

51 Jabavu to Chesson, 2 July 1887, APS papers, C139/11.

52 Jabavu to Chesson, 12 July 1887, APS papers, C139/12.

53 Jabavu to Chesson, 12 July 1887, APS papers, C139/12.

${ }^{54}$ Jabavu to Chesson, 12 July 1887, APS papers, C139/12.

55 Jabavu to Chesson, 29 August 1887, APS papers, C139/16.

${ }^{56}$ Jabavu to Chesson, 19 September 1887, APS papers, C139/18.

${ }^{57}$ APS, "The Native Franchise Question at the Cape," The Aborigines' Friend (October 1887): 425-26.

${ }^{58}$ British House of Commons, "The Cape Colony_-The Colonial Registration Bill." HC Deb, 7 July 1887, vol 317, c 73.

${ }^{59}$ APS to Henry Holland, 31 October 1887, quoted in APS, "The Native Franchise Question at the Cape," The Aborigines' Friend (March 1888): 483.

${ }^{60}$ Jabavu to Chesson, 19 September 1887, APS papers, C139/18.

${ }^{61}$ APS, “The Native Franchise Question at the Cape," The Aborigines' Friend (October 1887): 424-25.

${ }^{62}$ Timothy J. Stapleton, Faku: Rulership and colonialism in the Mpondo Kingdom (c. 1780-1867) (Waterloo, Ont: Wilfrid Laurier University Press, 2001), 131-34.

${ }^{63}$ William Beinart, The Political Economy of Pondoland: 1860-1930 (Cambridge: Cambridge University Press, 1982), 31.

${ }^{64}$ William Beinart, "European Traders and the Mpondo Paramountcy, 1878-1886," The Journal of African History 20/4 (October 1979): 476.

${ }^{65}$ Beinart, "European Traders and the Mpondo Paramountcy," 482. 
${ }^{66}$ Norman Etherington, Preachers, Peasants and Politics in Southeast Africa, 18351880: African Christian communities in Natal, Pondoland and Zululand (London: Royal Historical Society, 1978), 74.

${ }^{67}$ Beinart, "European Traders and the Mpondo Paramountcy, 1878-1886," 478.

${ }^{68}$ Beinart, "European Traders and the Mpondo Paramountcy, 1878-1886," 478-80.

${ }^{69}$ Beinart, "European Traders and the Mpondo Paramountcy, 1878-1886," 482.

${ }^{70}$ Mqikela to Chesson, 1 August 1883, APS papers, C149/103.

${ }^{71}$ Mqikela to Chesson, 8 February 1884, APS papers, C149/104.

${ }^{72}$ Mqikela to Chesson, 8 February 1884, APS papers, C149/104.

73 APS, "Umquikela and the Pondos," The Times, 20 October 1883, The Times Digital Archive, 9.

${ }^{74}$ APS, “The Case of the Pondos," The Aborigines' Friend (March 1884): 96-101.

${ }^{75}$ APS to the Colonial Office, 28 April 1884, in Irish University Press Series of British Parliamentary Papers: Colonies: Africa, vol. 27 (Shannon: Irish University Press, 1968), 373-76.

${ }^{76}$ APS to Colonial Office, 28 April 1884, in Irish University Press Series of British Parliamentary Papers: Colonies: Africa, vol. 27, 374.

${ }^{77}$ British House of Commons, "South Africa—Pondoland-The Chief Umquikela," HC Deb, 12 August 1884, vol 292, c 604.

${ }^{78}$ Mqikela to Chesson, 12 July 1884, APS papers, C149/105.

${ }^{79}$ Mqikela to Chesson, 12 July 1884, quoted in APS, "The Annual Report," The Aborigines' Friend (December 1884): 165.

${ }^{80}$ Aborigines' Protection Society, “The Annual Report," The Aborigines' Friend (December 1884): 165.

${ }^{81}$ Guy Aiken and Matthew Hedstrom, "Religious Society of Friends (Quakers)," in The SAGE Encyclopedia of War: Social science perspectives, edited by by Paul Joseph (Thousand Oaks: SAGE Publications, 2017).

${ }^{82}$ Swaisland, "The Aborigines' Protection Society," 16.

${ }^{83}$ Aborigines' Protection Society, The Proceedings of the Twenty-First Annual Meeting of the Aborigines' Protection Society (London: W. Tweedie, 1858), 6. ${ }^{84}$ Jeff Guy, The View Across the River: Harriette Colenso and the Zulu struggle against imperialism (Oxford: James Curry, 2002), 165. 
${ }^{85}$ Heartfield, The Aborigines' Protection Society, 43.

${ }^{86}$ Mqikela to Chesson, 1 August 1883, APS papers, C149/103.

${ }^{87}$ Mqikela to Chesson, 8 February 1884, APS papers, C149/104.

${ }^{88}$ Mqikela to Chesson, 12 July 1884, APS papers, C149/105.

${ }^{89}$ Colin Murray, Black Mountain: Land, class and power in the eastern Orange Free State, 1880s to 1980s (Washington: Smithsonian Institution Press, 1992), 19-20.

${ }^{90}$ R.L. Watson, “The Subjection of a South African State: Thaba Nchu, 1880-1884,” The Journal of African History 21/3 (1980): 360-61.

${ }^{91}$ Murray, Black Mountain, 21-26.

${ }^{92}$ Watson, "The Subjections of a South African State," 369.

${ }^{93}$ Paul Landau, Popular Politics in the History of South Africa, 1400-1948

(Cambridge: Cambridge University Press, 2010), 170.

${ }^{94}$ Paul Landua, 'The Spirit of God, Pigs and Demons: The 'Samuelites' of Southern Africa," Journal of Religion in Africa 29/3 (1999): 316.

${ }^{95}$ Landau, Popular Politics, 149.

${ }^{96}$ Landau, "The Spirit of God, Pigs and Demons," 316.

${ }^{97}$ Landau, Popular Politics, 150.

${ }^{98}$ Landau, Popular Politics, 163.

${ }^{99}$ Samuel Moroka to Chesson, 26 December 1883, APS papers, C143/63.

${ }^{100}$ Samuel Moroka to Chesson, 1 January 1884, APS papers, C143/64.

${ }^{101}$ Samuel Moroka to Chesson, 22 January 1884, APS papers, C143/66.

102 APS, “Samuel Moroka,” The Aborigines' Friend (March 1884): 102.

${ }^{103}$ Swaisland, “The Aborigines' Protection Society," 15.

${ }^{104}$ Richard Southey to Chesson, 24 January 1884, APS papers, C149/205.

105 Swaisland, "The Aborigines' Protection Society," 18.

${ }^{106}$ For an overview of these political missions to England, see Neil Parsons, "Southern African Royalty and Delegates visit Queen Victoria, 1882-1895," in Mistress of Everything: Queen Victoria in Indigenous Worlds, edited by Sarah Carter and Maria Nugent (Manchester: Manchester University Press, 2016), 166-86.

107 Willan, “The Anti-Slavery and Aborigines' Protection Society,” 87.

${ }^{108}$ Laidlaw, "Indigenous Interlocutors," 133. 
${ }^{109}$ Gwilym Colenso, "Breaking with the Old Pattern of Control: African deputations to Britain from Southern Africa in the late nineteenth and early twentieth centuries," South African Historical Journal 69/4 (2017): 532.

${ }^{110}$ Colenso, "Breaking with the Old Pattern of Control," 505.

111 Colenso, "Breaking with the Old Patterns of Control," 525-26.

${ }^{112}$ Laidlaw, "Indigenous Interlocutors," 134. 